\title{
16
}

\section{THE EU CODE OF PRACTICE ON DISINFORMATION AND THE RISK OF THE PRIVATISATION OF CENSORSHIP}

\author{
Matteo Monti
}

\section{Introduction}

The Internet ecosystem has completely transformed the way in which we consume information, and the role of social networks and search engines in spreading news the so-called "platformisation of news distribution" (Martens et al. 2018: 15) - is increasing rapidly. The transformation of the media environment brought about by the Internet platforms has weakened the role of journalists as gatekeepers of news as highlighted in the report of the Committee on Culture, Science, Education and Media (2017: 3); Levi (2012: 1555-72) talked about "deinstitutionalization of the press" - passing this role "to engineers, coders, and designers" (Carroll 2017: 71), and has created a commingling of different phenomena that has been called 'information disorder' (Wardle 2019; cf. Bayer 2019). The main problem with this disorder is that the mix of political propaganda, foreign influences, disinformation, satire, and other phenomena has undermined the classic legal categories regarding the media and the limits on the freedom of expression and information (Koltay 2019: 45). Given the ambiguity of the term 'freedom of information' - which can mean the right of access to public data or the freedom to inform and receive information and news in a broader sense - it is necessary to specify that this expression is given the second of these meanings in this chapter. ${ }^{1}$ In this framework, the lack of regulation of Internet platforms, ${ }^{2}$ and the fact that the rules of journalism do not cover them, ${ }^{3}$ has led to the spread of fake news (rectius disinformation). ${ }^{4}$

The aim of this chapter is to analyse the action of the European Union (EU) in particular the Code of Practice on Disinformation (the Code) - and its limits. To do this, the first section will analyse the legal framework of the EU action, while the second will study it in comparison with the initiatives developed by the Member States. Particular attention is paid here to the issue of the privatisation of censorship, which is taken to mean the delegation of powers to private actors in 
a field as important as that of fundamental rights. In the Conclusion, some general considerations are developed, by summarising the limits of the EU action and by looking forward to the development of some forms of control over the actions of the Internet platforms.

\section{The genesis and the limits of the EU action in the struggle against fake news}

The effort to contain online disinformation started as a reaction against the possibility that there were external influences in the European democratic system. ${ }^{5}$ The first step was a resolution of the European Parliament (EP) "to analyse in depth the current situation and legal framework with regard to fake news and to verify the possibility of legislative intervention to limit the dissemination and spreading of fake content." In January 2018, a High Level Group was established by the European Commission to develop strategies to counter the spread of fake news and finally, in September 2018, the Code of Practice on Disinformation was 'enacted'. The Code is a soft law tool that suggests to its signatories - among whom are the most important Internet platforms such as Google, Facebook, and Twitter - some possible strategies and practices to avoid the spread of fake news.

The most important of these actions are: (1) to avoid giving financial support to fake news factories through advertisements; (2) to dilute the visibility of fake news and to improve the 'findability' of trustworthy content; (3) to prioritise relevant, authentic, and authoritative information and to invest in technology to reinforce this prioritisation; (4) to ensure there is transparency in advertisements and sponsored content; and (5) to remove false accounts and regulate the activity of bots on platforms. This summary shows how this soft law instrument is having a great impact on the freedom of information (or press freedom), that is, the right to impart and receive news and information.

In this paragraph, the legitimacy of the actions undertaken by the EU will be analysed. Given the limited scope of application of Article 11 of the EU Charter of Fundamental Rights and the absence of specific case law of the Court of Justice of the European Union (CJEU) (Pollicino 2020: 9), the analysis will look at the European Convention on Human Rights (ECHR), particularly Article 10. In relation to this, one can recall the fact that Article 52.3 of the Nice Charter establishes that if there are rights corresponding to ECHR rights, the meaning and the scope of those rights shall be the same. Article 52.3 allows us to speculate on whether fake news can be considered as a protected expression under the European freedom of expression and information paradigm - as is the case in the United States by looking at the European Court of Human Rights (ECtHR) case law.

Before analysing the issue of the protection of fake news as free speech, it is important to stress another aspect of the EU initiative: it is forged in a way that does not touch sectors that are not harmonised, and it does not affect the Member States' fundamental rights. 
It is necessary to focus now on the case law of the ECtHR. The ECtHR has recognised a right to be informed and to receive news, ${ }^{7}$ the urgency of protecting pluralism in the media environment, ${ }^{8}$ the necessity for journalists to act in good faith and to respect the 'duties and responsibilities' of journalism if they are to obtain the protection of Article 10 of the ECHR, ${ }^{9}$ and the need to check information and news sources. ${ }^{10}$ The Court has specified that even in the exercise of free speech based on value judgments, which is slightly different from the right to spread news and information, there are some circumstances in which events and facts cannot be invented:

a distinction needs to be made between statements of fact and value judgments in that, while the existence of facts can be demonstrated, the truth of value judgments is not susceptible of proof. (. . .) However, where a statement amounts to a value judgment, the proportionality of an interference may depend on whether there existed a sufficient 'factual basis' for the impugned statement: if there was not, that value judgment may prove excessive. ${ }^{11}$

In this sense, it can be concluded that fake news certainly cannot be considered as protected speech in the field of the press, that is, if the news is diffused as a piece of journalism. More controversial is the application of the concept of fake news to political propaganda, which can use lies - within the limits of defamation - in its development (Monti 2018). In this sense, it is evident that freedom of information faces more particular limits than does the general freedom of expression, being linked to the role played by the press in a democratic society, which is the role of the watchdog of democracy, informing citizens, making governments accountable, and furnishing the basis for public debate. It is important to stress that "[u]nlike in the US practice, European constitutions and the individual legal systems actively try to separate the freedom of speech from the freedom of the press" (Koltay 2019: 45).

As specified in the Introduction, in the digital world the situation is a bit more complex since it is not easy to identify whether we are in the presence of a piece of news, a political message, or something else. However, extrapolating some principles from the case law of the ECtIR, it is possible to explore and use the 'traditional' legal categories to frame some of the new phenomena on Internet platforms. The Court, indeed, has, on the one hand, widened the definition of the media ${ }^{12}$ that are constrained by the rules of journalism ${ }^{13}$ and has, on the other hand, applied the limits of the freedom of information to journalists engaging in activities that are different from traditional news reporting (as in the case of comments posted on a forum). ${ }^{14}$ Thus, taking into consideration the fact that the rules of objective ${ }^{15}$ journalism can be adapted for different types of media, as stressed in the Delfi $v$. Estonia case, ${ }^{16}$ the case law of the ECtHR makes it possible to imagine a widening of the scope of application of the rules on freedom of information to new media 
such as websites, blogs, and social network pages (which could be classified as types of newspaper because of their aim) or to journalists' activities on the Internet and on social networks (e.g. Facebook posts or tweets).

In this context, however, it is necessary to underline that the types of selfproduced media content (Croteau 2006; Cram 2015) are changing, and that more and more often it is possible to see disinformation circulating in memes or social network posts without any mention of a website or the work of a journalist (Wardle 2019; this aspect may be linked to the collective credulity that seems to operate on the web: cf. Mocanu et al. 2015). Regardless of this, the ECtHR seems to have held that even an individual who cannot be defined as a journalist is bound by the rules applicable to journalists when he or she is engaged in spreading news and information in a public debate:

[t]he Court reiterates that the protection of the right of journalists to impart information on issues of general interest requires that they should act in good faith and on an accurate factual basis and provide 'reliable and precise' information in accordance with the ethics of journalism (. . .). The same principles must apply to others who engage in public debate. ${ }^{17}$

Additionally, the ECtIR has affirmed that even a self-regulatory body of internet service providers has to respect the principles developed for the press in some circumstances. ${ }^{18} \mathrm{~A}$ broad application of these principles in the world of Internet platforms would lead to a revolution in the regulation of the giants of the web.

Moreover, in the case of Brzezinski v Pologne - the first case in which the term 'fake news' was used in a European decision - the Court "admet qu'il est nécessaire de lutter contre la dissémination d'informations fallacieuses à propos des candidats aux élections afin de préserver la qualité du débat public en période préélectorale." ${ }^{19}$ Even while censoring the way in which the Polish courts managed the issue - an imprecise piece of news diffused by a mayoral candidate - the Court seems to have considered the censorship of fake news to be consistent with Article 10 of the Convention, despite the fake news having been diffused by a political actor in a public political debate. In this sense, it seems that the use of the term fake news is a little dangerous in the context of political debate, because if we reconnect the term 'fake news' with the term 'disinformation' we are looking at the specific topic of the press, and then by applying these terms to political and value judgments we risk misunderstanding the categories. It is true that false statements made by politicians could be censored (e.g. as defamation), but it is important not to apply the strict press rules to actors engaged in spreading political propaganda and not in diffusing news and information as journalists. ${ }^{20}$ In this sense, the EU's action in drafting the Code seems to contain a careful separation of the two categories, on the one hand ensuring that sponsored political content is clearly understood as such, and on the other favouring authentic news. ${ }^{21}$ 
Therefore, seconding Katsirea's argument (Katsirea 2018: 173) and focussing on the case law of the ECtHR, it is possible to defend that the paradigm of the press is susceptible to be legitimately applied to the digital world as well. As a consequence, fake news cannot be considered as a protected expression under Article 10 ECHR. Accordingly, using the words of Pollicino, "[t]he real challenge in Europe is not then - as in the US - if the issue of fake news can be tackled legally, but rather how this can be done in order to avoid a disproportionate restriction on the fundamental rights at stake, above all the freedom of speech" (Pollicino 2019a).

To conclude, it is possible to state that, so long as the EU does not invade fields that are not harmonised, the actions it has taken to force Internet platforms to selfregulate and avoid the spread of fake news seem to be consistent with its nature. Indeed, on the one hand, the EU's action does not prevent Member States from taking further initiatives and does not infringe on national fundamental rights; on the other hand, the EU's action is consistent with Article 10 ECHR.

\section{The double challenge of fighting fake news and avoiding the privatisation of censorship}

The Code can be framed as part of a broader general trend that delegates to Internet platforms the process of balancing fundamental rights online, the socalled "privatisation of censorship" (Tambini, Leonardi, and Marsden 2008). For instance, the German NetzDG ${ }^{22}$ establishes that, after notification to a social network by any user, hate speech and illegal false content (Claussen 2018: 118) must be removed by the social network itself within 24 hours (or seven days as required by Art. 3(2)), without any check by the public authorities (courts or independent authorities). This procedure has been criticised by those who believe that users' fundamental rights to free speech on Internet platforms should be protected. ${ }^{23} \mathrm{~A}$ very similar delegation of power to private actors would have been granted by the two proposed laws developed in the Italian legal order to fight fake news. The first one, the so-called Gambaro project, provided (among other articles) for the need for Internet platforms to undertake a general monitoring obligation for removing fake news and to allow the possibility of complaints by users against fake news. ${ }^{24}$ The second one, the Zanda-Filippin project, was inspired by the German law and required social networks to remove illegal content after a complaint. ${ }^{25}$ Both procedures were devoid of public authority control (by judges or independent authorities). Italian scholars have also underlined the 'constitutional' role that Internet platforms would have played in this case. ${ }^{26}$ In this scenario, the only law embracing a paradigm not involving the privatisation of censorship is the French one, ${ }^{27}$ which requires a judge to check the nature of online fake news before its removal. However, it is important to stress that the French law only concerns electoral periods and candidates in an election, ${ }^{28}$ thus appearing to be more a law regulating political communication in electoral periods than a law on the freedom of information. 
Moreover, the Code of Practice also can be framed - partially - within the European approach to fundamental rights online, which is highlighted by the Code of Conduct on Countering Illegal Hate Speech (referred to here as the Code of Conduct) and the CJEU case law on the right to be forgotten. This approach, too, involves the privatisation of censorship. From the first point of view, the Code of Conduct requires Internet platforms to remove content that includes illegal hate speech after a report by a user. ${ }^{29}$ The EU Commission has claimed that

[t] he balance between freedom of speech and what is prohibited illegal hate speech is set out in European case law, starting with the Jurisprudence of the European Court of Human Rights (. . .). It is neither a privatisation of justice nor is it excessive to ask all companies to do the same when they are notified about the existence of illegal content on their services. ${ }^{30}$

However, despite the claims of the Commission, it is clear that the balance is drawn by the Internet platforms, which can decide how to act and can proceed to censor content (Zhen Gan 2017: 118; Article 19 2016: 16). In a very similar way, the CJEU has legitimised, after the Google Spain decision ${ }^{31}$, the possibility of Internet platforms developing an autonomous balance between Internet users' right to be informed and the right to be forgotten (Pollicino and Romeo 2016: 249). As a consequence, in the European scenario, both at the EU level and the level of the Member States, there seems to be a trend that encourages and favours the privatisation of censorship. Indeed, most policies of the Member States and the European Union appear to be directed away from guaranteeing the freedom of expression and information on Internet platforms by not subjecting the actions taken by private actors against online content to checks by judges or independent authorities (and granting no effective right of appeal against the decisions of the Internet platforms).

Against this background, the Code of Practice on Disinformation is partially aligned with this trend by delegating to Internet platforms the obligation to remove fake accounts, and by favouring 'authentic' news.

Taking into account the practices developed by Google and Facebook, the two main actors in the search engine and social networks markets, respectively, it has to be stressed that the Code has delegated important content-based choices to the Internet platforms.

Indeed, both Google and Facebook remove 'profiles' that engage in the spread of fake news, the first one by giving a negative ranking to untrustworthy websites, ${ }^{32}$ and the second by removing from social networks those pages and personal accounts that participate in campaigns characterised by 'Coordinated Inauthentic Behavior' (CIB) ${ }^{33}$ or that simulate different identities (Lyons 2018). These actions have an effect on content, because giving a negative rank to a website makes it difficult for users to reach it, and removing a page or a personal account from Facebook affects all the content diffused on that page or account. These actions involve the actual risk of the removal of political speech or media 
content that are not approved of by the Internet platform or the private actors behind it, or simply the removal of content because of pressure by the majority of users and/or for economic reasons. Imagine what a campaign of notices against some information and pages or websites by users coordinated by political actors could generate. In addition, the risk of the general removal of all reported content to avoid any future fines or 'reactions' by the EU is an equally dangerous perspective. $^{34}$

From the second point of view, privileging some content over other content on the basis that it is the 'most authentic' news has a strong impact on pluralism. In the US, for instance, Internet platforms have been accused of setting their algorithms to favour progressive news over conservative news (Koltay 2019: 196). The European system is very sensitive to this matter, and independent authorities usually watch over pluralism on the media ecosystem.

It is, thus, important to underline how the Code of Practice - even if it does not encourage the removal of content - ends up increasing private censorship in the Internet ecosystem. Regarding the topic of private censorship, it is necessary to underline that in the EU framework a specific guarantee against private censorship seems to be absent, ${ }^{35}$ while in the ECHR system (Koltay 2019: 94), the Declaration of the Committee of Ministers on Human Rights and the Rule of Law in the Information Society ${ }^{36}$ and Recommendation CM/Rec(2011) $7^{37}$ on intermediaries committed the Member States to preventing private censorship. Focussing on the recent case law of the two European Courts, it is possible to see two different approaches. The European Court of Justice, in the recent case of Glawischnig Piesczek v. Facebook, ${ }^{38}$ has taken an ambiguous stance. On the one hand it has not taken into consideration - contrary to what was proposed by the Advocate General ${ }^{39}$ - the need for a check on the removal of content by Internet platforms (a right of appeal against their decisions) in order to guarantee the freedom of expression of users of Facebook, but, on the other hand, it seems to exclude the possibility of removal without an automated process. ${ }^{40}$ However, what is clear is that the Court has not set out a strong defence of the right to freedom of expression online. By contrast, the ECtHR has started to explore the issue of the privatisation of online censorship, excluding its presence in the activities of news portals, ${ }^{41}$ because "there are ample opportunities for anyone to make his or her voice heard on the Internet."42 It seems that the Court could consider the presence of a private censorship if there were no alternatives available: in this sense, it is interesting to consider whether the reasoning of the Court would change if it was contemplating the censorship activities of Facebook or Google, given the de facto monopoly under which they operate in the European market and their importance for public discourse (Koltay 2019: 185; cf. Hindman 2018).

This position would be very similar to the proposal by certain US scholars (Klonick 2018; contra: Peters 2017) to extend the so-called state action doctrine ${ }^{43}$ to Internet platforms to force them to respect users' rights of freedom of speech in the same way that governments must. ${ }^{44}$ 


\section{Conclusion}

The Code of Practice on Disinformation is a good attempt to give Internet platforms responsibility, to force them to attempt to counter the spread of fake news, and to rebuild the role of journalism on the Internet, with the intention of preserving the role of the press - in a broad sense - in European democracies.

However, the vital task of fighting disinformation online cannot be delegated entirely to Internet platforms in the way that the Code provides: the risks that dwell in the privatisation of censorship (in this case, the removal of politically oriented content instead of fake news, or the prioritisation of conservative news over progressive news or vice versa) are too big to be ignored. Indeed, Internet platforms have become too important as public forums to remain outside every type of legal regulation. In the specific field of fake news and the Code, granting a right of appeal to independent authorities against decisions made by platforms and establishing a general monitoring system for the operations of Internet platforms in the matter of pluralism, with both tasks being assigned, for instance, to the Body of European Regulators of Electronic Communications in coordination with the independent national authorities, could be sufficient to ensure that Internet platforms do not distort democracy.

\section{Notes}

1 "The European Convention on Human Rights and the constitutions of the European states recognize, for example, freedom of information as a qualified part of freedom of speech; and they present that freedom in three different modes: active (freedom to inform, or to spread information), passive (freedom to receive information), and medium (freedom to search for information)" (Pollicino 2020: 16).

2 For a study of the Italian legal system, as a prototype case for investigating the topic of freedom of information - to be interpreted as the freedom to inform and the right to be informed and receive news - see Monti (2017). On the power given to Internet platforms because of the lack of regulation: Tutt (2014:241).

3 On the form of the 'production' and distribution of news and the media logic of Internet platforms, see Klinger and Svensson (2015: $1246 \mathrm{ff}$.).

4 For the purposes of this chapter, fake news is news (sold as an output of journalism) that is invented and false (that is, it is based on invented or non-existent facts or events). Fake news is thus used as a synonym for disinformation. From this point of view the definition given by the EU 'Code of Practice on Disinformation' (2018) is quite interesting: disinformation is "verifiably false or misleading information" which, cumulatively, (a) "Is created, presented and disseminated for economic gain or to intentionally deceive the public;" and (b) "May cause public harm," intended as "threats to democratic political and policymaking processes as well as public goods such as the protection of EU citizens' health, the environment or security" (Code, Preamble). The Code excludes from this notion "misleading advertising, reporting errors, satire and parody, or clearly identified partisan news and commentary." For a broader analysis of how fake news circulates on Internet platforms, see Monti (2018).

5 European Council conclusions, 19-20 March 2015 (EUCO 11/15).

6 European Parliament resolution of 15 June 2017 on online platforms and the digital single market (2016/2276(INI)).

7 Ex pluribus: Observer and Guardian v. the UK App no. 13585/88 (ECtHR, 26 November 1991), $\$ 59$; Guerra and Others v. Italy 116/1996/735/932 (ECtHR, 19 February 1998), $\$ 53$. 
8 Ex pluribus: Centro Europa 7 stl and Di Stefano v. Italy App no. 38433/09 (ECtHR, 7 June 2012), $\$ 129-134$.

9 Ex pluribus: Fressoz and Roire v. Francia App no. 29183/95 (ECtHR, 21 January 1991), $\$ 54$; Movicar v. The UK App no. 46311/99 (ECtHR, 7 May 2002), $\$ 73$.

10 Fuchsmann v. Germany App no. 71233/13 (ECtHR, 19 October 2017), $\$ 43$. On proportionality see: Prager and Oberschlick v. Austria App no. 15974/90 (ECtHR, 26 April 1995), $\$ 37$. However it has to be remembered that also the press could exaggerate the terms of an issue: Ibid., $\$ 38$. The duty of checking sources is weaker in the political speech field as in the case of trustfulness in journalists' works: Salov v. Ukraine App no. 65518/01 (ECtHR, 6 December 2005), $\$ 113$.

11 GRA Stiftung gegen Rassismus und Antisemitismus v Switzerland App no. 18597/13 (ECtHR, 9 January 2018), $\$ 68$.

$12 \$ 7$ of Recommendation CM/Rec(2011)7. Cf. Koltay (2019: 46 and ff.).

13 'The broad definition of the 'media' adopted by the Court suggests that new media engaged in the spread of 'fake news' would be held to account for failing to act in good faith and to verify untruthful allegations" (Katsirea, 2018: 173).

14 "Nevertheless, it is clear that, by posting under the username 'Eynulla Fatullayev', the applicant, being a popular journalist, did not hide his identity and that he publicly disseminated his statements by posting them on a freely accessible popular Internet forum, a medium which in modern times has no less powerful an effect than the print media." Fatullayev v. Azerbaijan A no. 40984/07 (ECtHR, 4 October 2010), $\$ 95$.

15 'Objective' does not mean impartial or with an absence of bias (Cf. American Press Institute, "The lost meaning of "objectivity", available at: www.americanpressinstitute.org/ journalism-essentials/bias-objectivity/lost-meaning-objectivity.

16 Delfiv. Estonia App no. 64569/09 (ECtHR, 16 June 2015), $\$ 134$.

17 Braun v. Poland App no. 30162/10 (ECtHR, 4 February 2015), $\$ 40$.

18 "The Court notes that both the first applicant, as a self-regulatory body of internet service providers, and the second applicant, as a large news portal, provided forum for the exercise of expression rights, enabling the public to impart information and ideas. Thus, the Court shares the Constitutional Court's view according to which the applicants' conduct must be assessed in the light of the principles applicable to the press." Magyar Tartalomszolgáltatók Egyesïlete and Index.Hu Znt v. Hungary App no. 22947/13 (ECtHR, 2 May 2016), $\$ 61$.

19 Brzeziński c. Pologne App no. $47542 / 07$ (ECtHR, 25 July 2019), $\$ 55$.

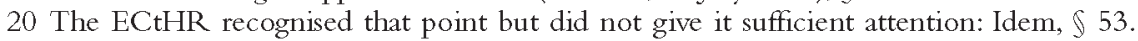
The only problem with this decision is probably the naive use of the term 'fake news' to describe a fact that is not connected with the activities of the press and cannot be completely described as online disinformation, in which some actors want to assume the role and authoritative power of the press to spread fake news that is described and sold as authentic news.

21 It is important to note that in the definition of disinformation the Code excludes the possibility that political information falls within the concept of disinformation. See note 4.

22 Netzwerkdurchsetzungsgesetz- NetzDG, 2017, $\$ 2$ and 3.

23 "Durch die Löschungen von Meinungen seitens der Betreiber sozialer Netzwerke wird auch die Informationsfreiheit (Art. 5 Abs. 1 Satz 1 GG) aller Nutzer beeinträchtigt", Liesching (2018: 28). And about the risk of a general removal of contents to avoid fines see ibid.: 27.

24 Art. 7, co. 2, Senate of the Italian Republic, proposal Gambaro, S. 2688-17 $7^{\mathrm{a}}$ Legislature.

25 Art. 2, Senate of the Italian Republic, proposal Zanda-Filippin, S. 3001-17 Legislature.

26 Bassini and Vigevani (2017: 20) talked of "un fortissimo spazio di discrezionalità, tale da poter insinuare la trasfigurazione della funzione di selezione in un'attività censoria o comunque svolta secondo un'impostazione 'di tendenza' e 'orientata'."

27 Loi no. 1202/2018. 
28 As stressed: "Il]e champ d'application de la loi ne regarde done que les périodes électorales et laisse donc en suspens la question des fake news qui surgissent hors des périodes d'élections ou qui ne concernent pas les candidats." Ponthoreau (2019:30).

29 EU Code of Conduct on countering illegal hate speech online (2016). Cf. Coche (2018).

30 Code of Conduct - Illegal online hate speech, Questions and answers, 2016, https:// ec.europa.eu/info/sites/info/files/code_of_conduct_hate_speech_en.pdf.

31 CJEU, Case C-131/12. The case concerns the balance between privacy and freedom of expression and information online, and it specifically relates to the right to be forgotten in the information and news diffused by search engines.

32 Last intermediate results of the EU Code of Practice against disinformation: Google May 2019 Report, 2.

33 Annual self-assessment reports of signatories to the Code of Practice on Disinformation: Facebook, 29 October 2019, 13.

34 It should be considered that "the European institutions themselves have promised to verify the effects of this initial form of cooperation, without excluding the possibility of 'raising the bar' with different types of interventions." Pollicino (2020: 13).

35 EU Human Rights Guidelines on Freedom of Expression Online and Offline, 19 May 2014; although the European Parliament recommendation of 26 March 2009 noted the fact the freedoms should "be protected adequately and effectively from intrusions by both private and public actors" (emphasis mine).

$36 \mathrm{CM}(2005) 56$-final 13 May 2005.

37 Recommendation CM/Rec (2011) 7 of the Committee of Ministers to Member States on a new notion of media, $₫ 63$.

38 CJEU, Case C-18/18.

39 Conclusions $A G$, case $C 18-18, \$ 65$.

40 According to Pollicino (2019b: 8), the Court would have tried to avoid delegating too many powers to the Internet platforms, as happened on the contrary in the right to be forgotten regime.

41 See Delfi v. Estonia, $\$ 157$.

42 See ibid., $\$ 137$.

43 According to the US Supreme Court, when a private actor - for instance, a so-called company town - is functionally equivalent to a state actor, the private actor has to guarantee First Amendment rights in the same way as a government by, for instance, avoiding censorship. The leading case in this field is Marsh v.Alabama, 326 U.S. 501 (1946). For an analysis of the US Supreme Court case law and its scrutiny see Klonick (2018: 1609 and ff.).

44 For now this theory was rejected by federal circuits (Johnson v. Twitter, Inc., n. 18ECG00078 (Cal. Superiore Ct. 6 giugno 2018); Williby v. Zuckerberg, 3:18-cv-06295-JD (N.D. Cal. June 18, 2019)) and according to some scholars, the US Supreme Court has decided to not take a position about the issue in the decision Manhattan Community Access Corp.v. Halleck, No. 17-1702, 587 U.S. (2019).

\section{References}

Article 19 (2016) 'EU: European Commission's Code Of Conduct for Countering Illegal Hate Speech Online and the Framework Decision', 14 June 2016, www.article19.org/ data/files/medialibrary/38430/EU_Code-of-conduct-analysis-FINAL.pdf (last consulted 20 March 2020).

Bassini, M., G.E. Vigevani (2017) 'Primi appunti su fake news e dintorni', Medialaws 1: 11. Bayer, J. (ed.) (2019) 'Disinformation and propaganda - impact on the functioning of the rule of law in the EU and its Member States' (PE 608.864 - February 2019).

Carroll, C.E. (2017) 'Making news: Balancing newsworthiness and privacy in the age of algorithms', Georgetoun Law Joumal 106: 69. 
Claussen, V. (2018) 'Fighting hate speech and fake news. The Network Enforcement Act (NetzDG) in Germany in the context of European legislation', MediaLaws 3: 110.

Coche, E. (2018) 'Privatised enforcement and the right to freedom of expression in a world confronted with terrorism propaganda online', Internet Policy Review 7: 1.

Cram, I. (2015) Citizens Joumalists: Newer Media, Republican Moments and the Constitution, Cheltenham: Edward Elgar.

Croteau, D. (2006) "The growth of self-produced media content and the challenge to media studies', Critical Studies Media Communication 23: 340.

Hindman, M. (2018) The Internet Trap. How the Digital Economy Builds Monopolies and Undermines Democracy, Princeton: Princeton University Press.

Katsirea, I. (2018) "Fake news": Reconsidering the value of untruthful expression in the face of regulatory uncertainty', Joumal of Media Law 10: 159.

Klinger, U., J. Svensson (2015) 'The emergence of network media logic in political communication: A theoretical approach', New Media \& Society 17: 1241.

Klonick, K. (2018) 'The new governors: The people, rules, and processes governing online speech', Havvard Law Review 131: 1598.

Koltay, A. (2019) New Media and Freedom of Expression, Oxford: Hart.

Levi, L. (2012) 'Social media and the press', North Carolina Law Review 90: 1531.

Liesching, M. (2018) 'Die durchsetzung von verfassungs - und europarecht gegen das NetzDG - überblick über die wesentlichen kritikpunkte', MultiMedia und Recht 1: 26.

Lyons, T. (2018) 'Hard Questions: What's Facebook's strategy for stopping false news?', Facebook, 23 May 2018, https://about.fb.com/news/2018/05/hard-questions-falsenews (last consulted 20 March 2020).

Martens B., L. Aguiar, E. Gomez-Herrera, F. Mueller-Langer (2018) 'The digital transformation of news media and the rise of disinformation and fake news', JRC Tecnhical Reports 2018.

Mocanu, D., L. Rossi, Q. Zhang, M. Karsai, W. Quattrociocchi (2015) 'Collective attention in the age of (mis)information', Computers in Human Behavior 51: 1198.

Monti, M. (2017) 'Perspectives on the regulation of search engine algorithms and social networks', Opinio Iuris in Comparatione 1: 71.

Monti, M. (2018) 'The new populism and fake news on the Internet', Stals Research Papers 4: 1 .

Peters, J. (2017) 'The "sovereigns of cyberspace" and state action: The First Amendment's application (or lack thereof) to third-party platforms', Berkeley Technology Law Journal 32: 989.

Pollicino, O. (2020) 'Freedom of expression and the European approach to disinformation and hate speech: The implication of the technological factor', Liber Amicorum per Pasquale Costanzo, www.giurcost.org/LIBERAMICORUM/INDICEliber.html (last consulted 20 March 2020).

Pollicino, O. (2019a) 'Fundamental rights as bycatch - Russia's anti-fake news legislation', Verfassungsblog.

Pollicino, O. (2019b) "L'“autunno caldo" della Corte di giustizia in tema di tutela dei diritti fondamentali in rete e le sfide del costituzionalismo alle prese con i nuovi poteri privati in ambito digitale', Federalismi 19: 1.

Pollicino, O., G. Romeo (2016) 'Concluding remarks: Internet law, protection of fundamental rights and the role of constitutional adjudication', in: O. Pollicino, G. Romeo (eds.), The Internet and Constitutional Law. The Protection of Fundamental Rights and Constitutional Adjudication in Europe, Abingdon: Routledge.

Ponthoreau, M.-C. (2019) 'Liberté d'expression, une perspective de droit comparé: France', EPRS. 
Report of the Committee on Culture, Science, Education and Media (2017), 'Online media and journalism: Challenges and accountability', Council of Europe 2017, Doc. 14228.

Tambini, D., D. Leonardi, C. Marsden (2008) 'The privatisation of censorship: Self regulation and freedom of expression' in: D. Tambini, D. Leonardi, C. Marsden (eds), Codifying cyberspace: Communications Self-Regulation in the Age of Intemet Convergence, Abingdon: Routledge - UCL Press.

Tutt, A. (2014) 'The new speech', Hastings Constitutional Law Quarterly 41: 235.

Wardle, C. (2019) 'Understanding information disorder', (First Draft).

Zhen Gan, H. (2017) 'Corporations: The regulated or the regulators?', Columbia Joumal of European Law 24: 111. 